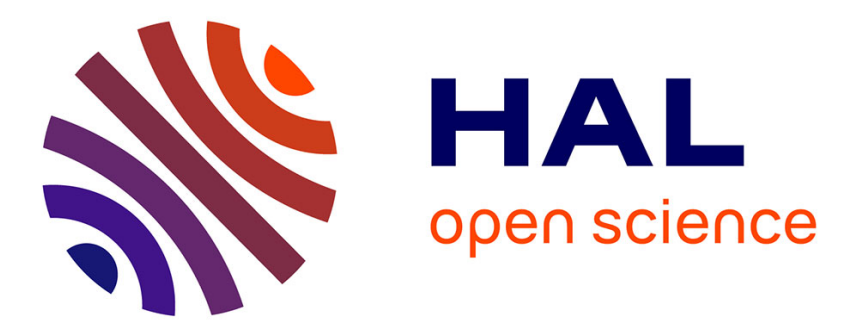

\title{
Identification of apolipoprotein A-I in the alpha-globulin fraction of avian plasma
}

Yannick Roman, Bertrand Bed'Hom, Alain Guillot, Julie Levrier, Daniel Chaste-Duvernoy, Marie-Claude Bomsel-Dementoy, Michel Saint Jalme

\section{- To cite this version:}

Yannick Roman, Bertrand Bed'Hom, Alain Guillot, Julie Levrier, Daniel Chaste-Duvernoy, et al.. Identification of apolipoprotein A-I in the alpha-globulin fraction of avian plasma. Veterinary Clinical Pathology, 2009, 38 (2), pp.206-212. 10.1111/j.1939-165X.2009.00142.x . hal-01193358

\section{HAL Id: hal-01193358 \\ https://hal.science/hal-01193358}

Submitted on 31 May 2020

HAL is a multi-disciplinary open access archive for the deposit and dissemination of scientific research documents, whether they are published or not. The documents may come from teaching and research institutions in France or abroad, or from public or private research centers.
L'archive ouverte pluridisciplinaire HAL, est destinée au dépôt et à la diffusion de documents scientifiques de niveau recherche, publiés ou non, émanant des établissements d'enseignement et de recherche français ou étrangers, des laboratoires publics ou privés. 


\title{
Identification of apolipoprotein A-I in the $\alpha$-globulin fraction of avian plasma
}

\author{
Yannick Roman ${ }^{1}$, Bertrand Bed'Hom ${ }^{2}$, Alain Guillot ${ }^{3}$, Julie Levrier ${ }^{1}$, Daniel Chaste-Duvernoy ${ }^{4}$, Marie-Claude \\ Bomsel-Demontoy ${ }^{5}$, Michel Saint Jalme ${ }^{6}$ \\ ${ }^{1}$ Le Parc de Clères, DJBZ, Muséum national d'Histoire naturelle, Clères, France; ${ }^{2}$ UMR1313 Animal Genetics and Integrative Biology, AgroParisTech, and \\ ${ }^{3}$ PAPSS, INRA, Jouy en Josas, France; ${ }^{4}$ Laboratoire Bio-VSM, Torcy, France; ${ }^{5}$ Ménagerie du Jardin des Plantes, DJBZ, and ${ }^{6}$ EGB, UMR 5173 - CERSB - MNHN, \\ CNRS, Paris IV, Muséum national d'Histoire naturelle, Paris, France
}

\author{
Key Words \\ Agarose gel electrophoresis, $\alpha$-globulin, \\ apolipoprotein A-I, avian, plasma protein \\ electrophoresis \\ Correspondence \\ Yannick Roman, Le Parc de Clères, Muséum \\ National d'Histoire Naturelle, DJBZ, 32 avenue \\ du Parc, 76690 Clères, France \\ E-mail: yannick.roman@cg76.fr \\ DOI:10.1111/j.1939-165X.2009.00142.x
}

Background: Plasma protein electrophoresis is frequently used in birds as a tool for the diagnosis and monitoring of disease. Identification of proteins in individual peaks can help improve our understanding of changes in protein concentration in physiologic and pathologic conditions.

Objective: The aim of this study was to verify the presence and identity the protein(s) in the prominent $\alpha$-globulin peak of orange-winged parrots ( $A m$ zonica), black kites (Milvus migrans), and rock pigeons (Columba livia).

Methods: Heparinized plasma samples were obtained from 12 birds of each species. Agarose gel electrophoresis and total protein concentration were determined using standard techniques. One plasma sample from each species was then electrophoresed using high-resolution agarose gels to isolate the $\alpha$-globulin band. Gel strips were digested in trypsin and peptides were extracted and analyzed using liquid chromatography with tandem mass spectrometry. De novo sequencing was used to identify the protein based on homology scoring against a protein database.

Results: Electrophoresis verified the presence of a single prominent $\alpha$-globulin peak, usually in the $\alpha_{1}$-region, that had a median concentration of $9.4 \mathrm{~g} / \mathrm{L}$ (range, $2.1-11.7 \mathrm{~g} / \mathrm{L}, 21.6 \%$ of total protein) in parrots, $12.2 \mathrm{~g} / \mathrm{L}$ $(10.4-13.2 \mathrm{~g} / \mathrm{L}, 35.9 \%)$ in kites, and $10.7 \mathrm{~g} / \mathrm{L}(9.0-11.5 \mathrm{~g} / \mathrm{L}, 40.0 \%)$ in pigeons. Mass spectrometry and sequencing analysis unequivocally identified the protein as a mature circulating form of apolipoprotein A-I (apo A-I) in all 3 species.

Conclusions: Apo A-I accounts for the prominent $\alpha$-globulin peak and comprises a major proportion of total protein concentration in diverse avian species. As a high-density lipoprotein and negative acute phase protein with a pivotal role in cholesterol homeostasis, further study is warranted to determine the significance of changes in apo A-I concentration in avian electrophoretograms.

\section{Introduction}

Within the last 15 years, the application of protein electrophoresis in clinical avian medicine has received considerable attention, and it is recognized as a useful diagnostic tool for the evaluation, diagnosis, and monitoring of a variety of diseases and conditions. ${ }^{1-3}$ Plasma proteins in electrophoretic gels are identified according to their electrophoretic mobility and immunoreactivity as either albumin or $\alpha_{-}, \beta-$, or $\gamma$-globulins. ${ }^{3}$ Some authors have demonstrated high intertaxonomic variations in plasma electrophoresis patterns. $^{2,4,5}$

We regularly use plasma protein electrophoresis as a diagnostic tool in our laboratory and have observed a prominent peak in the $\alpha$-globulin region in electrophoretic tracings from birds in various taxa including Columbiformes, Falconiformes, Strigiformes, Psittaciformes, Phoenicopteriformes, Charadriiformes, and Ciconiiformes (Y.R., unpublished data). Although 
the amplitude of the peak seems to depend on the species, its size is sufficiently large in some species such that it could lead to errors in the interpretation of electrophoretograms. Although 2 recent studies have noted the existence of this peak, neither has identified its origin. ${ }^{6,7}$ The purpose of the present study was to verify the presence and determine the composition of this unique $\alpha$-globulin peak in agarose gel electrophoretograms from 3 phylogenetically distant bird species.

\section{Materials and Methods}

\section{Experimental animals and samples}

The study was conducted on 12 rock pigeons, Columba livia ( 5 males, 7 females) at the zoological park of Clères (France), 12 black kites, Milvus migrans ( 7 males, 5 females) at the Académie de fauconnerie du Puy du fou (France), and 12 orange-winged parrots (Amazona amazonica) of unknown sex at the Zoo de Lille. Blood samples were performed on the occasion of a veterinary screening protocol. All of the birds were examined and determined to be clinically healthy.

Blood samples were taken from the right jugular vein of the black kites and orange-winged parrots, which is the preferred sampling site in avian species whose jugular veins are overlaid by a featherless tract of skin (apterium), and from the brachial vein of the rock pigeons. Samples were taken outside the breeding season, from September to December 2007, depending on the species, using $23 \mathrm{G}$ needles and $2 \mathrm{~mL}$ syringes (Terumo Europe N.V., Leuven, Belgium). Two milliliters of blood were drawn from each bird into lithium heparin Venosafe-evacuated blood collection tubes (Terumo Europe N.V., Leuven, Belgium), and centrifuged at $3000 \mathrm{~g}$ for 5 minutes. Plasma was removed and stored in cryotubes (Micronic Systems, Lelystad, The Netherlands) at $-20^{\circ} \mathrm{C}$ for $1-3$ weeks until analysis.

\section{Total protein concentration and plasma protein electrophoresis}

Samples were thawed and rehomogenized by gentle mixing 1 hour before analysis. Total protein concentration was determined by the biuret reaction at $552 \mathrm{~nm}$, using a Roche Integra 400 chemistry analyzer (Roche Diagnostics, Meylan, France). Agarose gel electrophoresis of plasma proteins was done using a Hydrasys semi-automated system (Sebia, Evry, France) and a Hydragel protein 15/30 set (Sebia). The system was operated according to the manufacturer's instructions, using version 7.00 F0.1 of the system software. Plasma samples $(10 \mu \mathrm{L})$ were applied manually and were allowed to diffuse for 5 minutes in a wet chamber. Sample application (30 seconds), electrophoresis ( $\sim 7$ minutes), and drying $\left(65^{\circ} \mathrm{C}\right.$ for 10 minutes) were done automatically in the migration compartment of the instrument. The temperature was maintained at $20^{\circ} \mathrm{C}$ using a Peltier device. Electrophoretic separation was obtained on $8 \mathrm{~g} / \mathrm{L}$ agarose gels in a Tris-barbital buffer (pH 9.2), at constant power level of $20 \mathrm{~W}$, until $33 \mathrm{Vh}$ had been accumulated. Dried gels were transferred manually to the staining compartment and stained automatically for 4 minutes with $4 \mathrm{~g} / \mathrm{L}$ amidoblack in an acidic solution, destained ( 3 times, for 3 and 2 minutes, and 1 minute) with $0.5 \mathrm{~g} / \mathrm{L}$ citric acid solution, and dried at $75^{\circ} \mathrm{C}$ for 8 minutes. Gels were then scanned with a high-resolution Epson Perfect V700 photo scanner (Epson France, Nanterre, France).

Electrophoretic curves and percentage values of the different fractions were determined using Phoresis software (version 5.50, Sebia). Albumin was identified as being the strongest anodal peak. In all of the species, the $\alpha$ fraction of interest was located in a position just cathodic to that of albumin. The concentration of protein in the $\alpha$-globulin fraction was determined by multiplying the relative fraction percentage by the total protein concentration.

\section{Separation and digestion of the $\alpha$-globulin band}

One plasma sample from each species was chosen randomly for electrophoresis using Hydragel 15HR highresolution gels (Sebia). Each sample was run twice on 2 distinct high-resolution gels. The first one was dried and stained according to the manufacturer's instruction and was used to locate the $\alpha$ band. The second one, for which the semi-automatic process was interrupted before the drying and staining steps, was used to cut out the $\alpha$ band of interest. The latter was accurately located by superimposing the nondried gel with the stained one. Gel strips cut out from the gel were placed in Eppendorf tubes (Eppendorf GA, Hamburg, Germany), and mailed under refrigerated conditions $\left(3^{\circ} \mathrm{C}\right)$ to the PAPSS (Plateau d'Analyse Protéomique par Séquençage et Spectrométrie de Masse) proteomic platform at INRA (Institut National de Recherche Agronomique, Jouy en Josas, France), for peptide de novo sequencing and protein identification.

Each gel gel strip was washed twice with $200 \mu \mathrm{L}$ $50 \mathrm{mM}$ ammonium carbonate in a $50 \%$ acetonitrile solution, dried at room temperature, and digested overnight at $37^{\circ} \mathrm{C}$ with $100 \mathrm{ng}$ of sequencing-grade modified trypsin (Promega, Madison, WI, USA) in $2 \mu \mathrm{L}$ of $50 \mathrm{mM} \mathrm{NH}_{4} \mathrm{HCO}_{3}$. The resulting peptides were extracted as follows: the supernatant from trypsin 
hydrolysis was first transferred into a new tube, and the gel slices were extracted once with $25 \mu \mathrm{L}$ of buffer extract-B (50 mM ammonium carbonate), and twice with $25 \mu \mathrm{L}$ of buffer extract-C (formic acid $0.1 \%$ acetonitrile $50 \%$ ). For each extraction, the gel slices were incubated for 15 minutes at room temperature under gentle shaking conditions. The 3 extracts were pooled with supernatant from the original trypsin digest and dried for 1 hour in a Speed-Vacuum concentrator (Savan, Thermo Fisher, Illkirch, France). The peptides were then resuspended in $25 \mu \mathrm{L}$ of precolumn loading buffer $(0.08 \%$ trifluoroacetic acid and $2 \%$ acetonitrile in water), before analysis.

\section{Mass spectrometric analysis}

Liquid chromatography coupled to tandem mass spectrometry (LC-MS/MS) analysis was performed with an Ultimate 3000 LC system (Dionex, Voisins le Bretonneux, France) connected by a nanoelectrospray interface to a linear ion trap mass spectrometer (LTQ, Thermo Fisher, Waltham, MA, USA). Four microliters of tryptic peptide mixtures from each sample were loaded at a flow rate of $20 \mu \mathrm{L} / \mathrm{min}$ onto a precolumn (Pepmap C18, $0.3 \times 5$ mm, $100 \AA, 5 \mu \mathrm{m}$; Dionex). After 4 minutes, the precolumn was connected to a separating Pepmap C18 nanocolumn $(0.075 \times 15 \mathrm{~cm}, 100 \AA$, $3 \mu \mathrm{m}$; Dionex) and the gradient was set to $300 \mathrm{~nL} / \mathrm{min}$. All peptides were separated in the nanocolumn using modified buffer elut-B with a linear gradient of acetonitrile from $2 \%$ to $36 \%$, for 18 minutes. The eluting buffers were buffer elut-A: $0.1 \%$ formic acid, $2 \%$ acetonitrile and buffer elut-B: $0.1 \%$ formic acid, $80 \%$ acetonitrile. The total run length was 50 minutes, including the regeneration step. Ionization was performed at the liquid junction, with a spray voltage of $1.3 \mathrm{kV}$ applied to a noncoated capillary probe (PicoTip Emiter, $10 \mu \mathrm{m}$ ID; New Objective, Woburn, MA, USA). The peptide ions were analyzed using the Nth-dependent method as follows: (1) full mass spectrometry scan ( $m / z$ 300-2000); (2) ZoomScan (scan of the 3 major ions); and (3) MS/MS on these 3 ions using standard peptide fragmentation parameters $(Q z=0.25$, activation time $=30 \mathrm{~ms}$, collision energy $=40 \%$ ).

\section{Protein identification by de novo sequencing and homology scoring}

Protein identification was carried out using Peaks Studio 4.2 software (Bioinformatic Solution, Waterloo, ON, Canada), together with the FASTS tools (available for free at: http://www.ebi.ac.uk/fasta33/). Raw data were first loaded into Peaks Studio and filtered to eliminate noisy spectra. Filtered MS/MS spectra were rap- idly translated into amino acid sequences, with several de novo sequencing parameters: parent and fragmentmass error tolerances of $0.5 \mathrm{Da}$, trypsin as the protease, with a maximum of 1 missed cleavage allowed, and partial oxidation of methionine. All of the sequences produced by Peaks Studio were then filtered, so as to retain only those with peaks scoring higher than 50\% on doubly charged ions. These short sequences were analyzed with FASTS against the Uniref100 protein database, with MDM20 as the selected matrix. The identified proteins were classified by homology scoring, according to their expectation value ( $E$-value), reflecting the significance of the score.

\section{Statistical analysis}

Descriptive statistics were calculated (Microsoft Excel 2003, Microsoft Corp., Redmond, WA, USA). Kruskal-Wallis 1-way ANOVA was used to study the difference in $\alpha$-globulin fractions concentrations between species and Mann-Whitney $U$-test was used to determine differences in $\alpha$-globulin fractions concentrations between sexes within each species (Systat 7.0, Systat Software Inc., London, UK).

\section{Results}

The electrophoretic patterns of the 3 species were similar and included a prominent narrow peak in the $\alpha$-globulin fraction (Figure 1). However, the studied species differed from one another in their $\alpha$-globulin concentration $(U=21.275 ; \quad P<.01)$. The $\alpha$-globulin peak had a median concentration of $9.4 \mathrm{~g} / \mathrm{L}$ (range, $2.1-11.7 \mathrm{~g} / \mathrm{L} ; 21.6 \%$ of total protein) in parrots, $12.2 \mathrm{~g} / \mathrm{L}(10.4-13.2 \mathrm{~g} / \mathrm{L}, 35.9 \%)$ in kites, and $10.7 \mathrm{~g} / \mathrm{L}$ $(9.0-11.5 \mathrm{~g} / \mathrm{L}, 40.0 \%)$ in pigeons. No significant difference was found between males and females in the $\alpha$-globulin fractions within the 3 species studied.

LC-MS/MS analysis of peptides resulting from trypsin digestion of proteins in the $\alpha$-globulin peak is shown in Figure 2. Based on homology with sequences in the Uniprot database, apolipoprotein A-I (apo A-I) was identified as the main protein in the $\alpha$-globulin peak in samples from all 3 species. The highest similarity was observed with apo A-I from duck, chicken, quail, and turkey, in which highly significant hits $\left(E\right.$-values, $\left.1.9 \times 10^{-34}-6.5 \times 10^{-71}\right)$ with large coverage (49.6-74.8\% of hit sequence length) corresponded to apo A-I. The 24 amino acids of the apo A-I aminoterminal region were not represented in fingerprints, probably indicating a truncated mature form of the protein. Few less-significant hits corresponded to more distantly related mammalian apo A-I. All other 

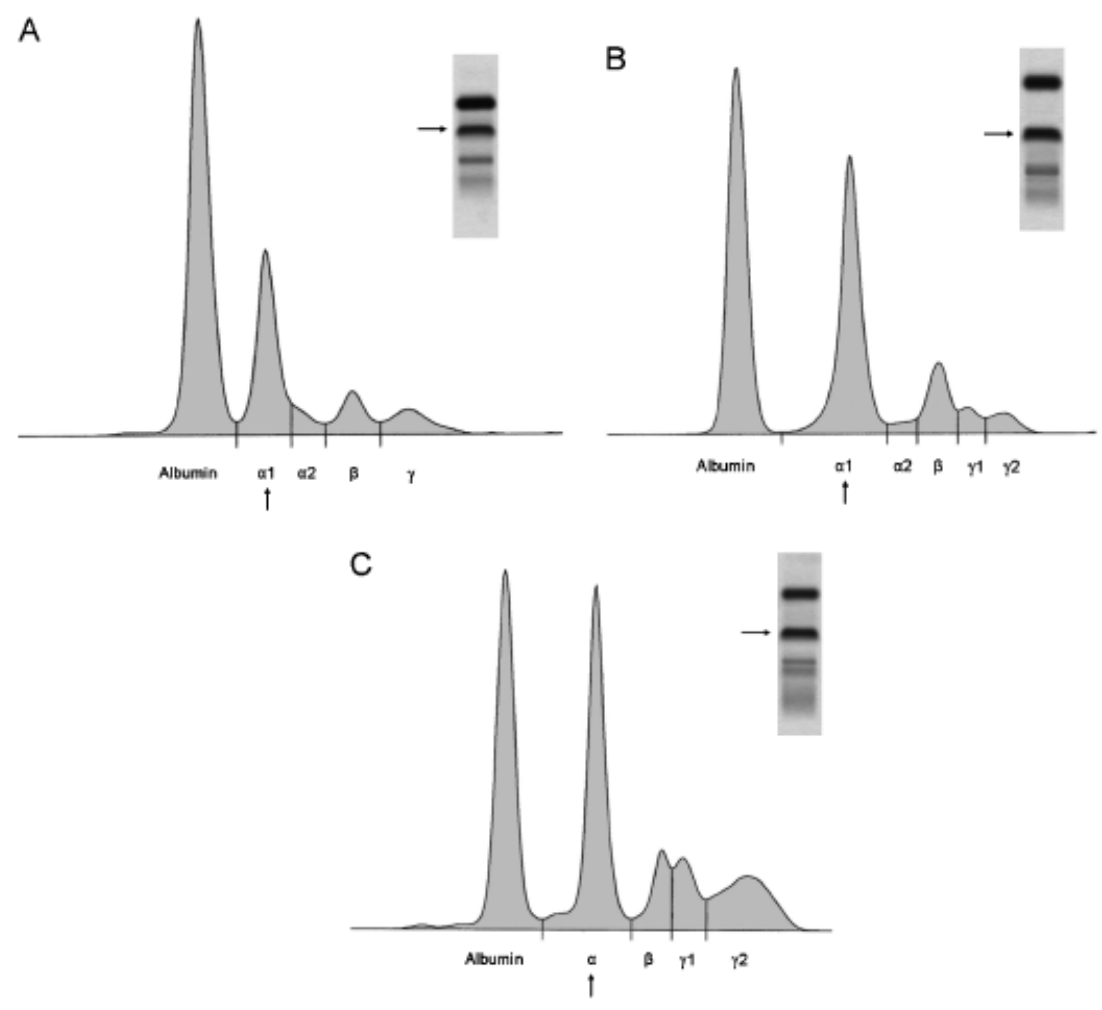

Figure 1. Representative plasma protein electrophoretic pattern from an (A) orange-winged parrot (Amazona amazonica), (B) black kite (Milvus migrans), and (C) rock pigeon (Columba livia). The $\alpha$-globulin peak of interest is indicated with an arrow.

significant hits corresponded to human keratins and cytokeratins, which were interpreted as contaminants, and to porcine trypsin, which was used during sample preparation to generate peptides.

\section{Discussion}

For the first time, a high-amplitude peak in the $\alpha$-globulin region of birds was identified, as apo A-I. The same apolipoprotein peak was observed in 3 species belonging to distant bird taxa (Psittaciformes, Falconiformes, and Columbiformes).

We found only 2 articles written in the past 30 years that mention the existence of a prominent peak in the $\alpha$-globulin fraction similar to that described in the present study. Tatum et al. ${ }^{8}$ described a high-amplitude $\alpha_{1}$-globulin fraction in Falconiformes and Strigiformes that was positioned just at the edge of the albumin peak. More recently, pigeons were found to have relatively high $\alpha$-globulin concentrations, in comparison with ducks and turkeys. ${ }^{9}$ Neither of these studies shed light on the molecular origin of the protein(s) in the $\alpha$-globulin peak. It is interesting to note that these studies are also the only ones that used agarose gel electrophoresis for evaluating plasma proteins from Falconiformes and Columbiformes; all other studies used cellulose acetate electrophoresis (Falconiformes $^{10-13}$ and Columbiformes $\left.{ }^{14,15}\right)$. The poorer resolution of the latter technique, in comparison with agarose, could be the reason why the $\alpha$-globulin peak was not observed. To our knowledge, a prominent peak in the $\alpha$-globulin region has not been described previously in Psittaciformes in studies based on agarose gel $^{6}$ and cellulose acetate ${ }^{16-18}$ electrophoresis. As described earlier in Falconiformes and Columbiformes, this could be related to the poorer resolution of cellulose acetate electrophoresis. However, in their recent article on plasma protein electrophoresis in Psittacidae, Cray et $\mathrm{al}^{6}$ obtained reference values for $\alpha$-globulin fractions in multiple species that did not exceed $9 \%$ of the total protein content with agarose gel electrophoresis. This could be because of the fact that their electrophoretic parameters (Beckman Paragon SPEP-II gel system; migration obtained with $100 \mathrm{~V}$ for 37 minutes) were different from those used in our study.

The comparison of peptide sequences obtained from the $\alpha$-globulin bands with protein sequences in 


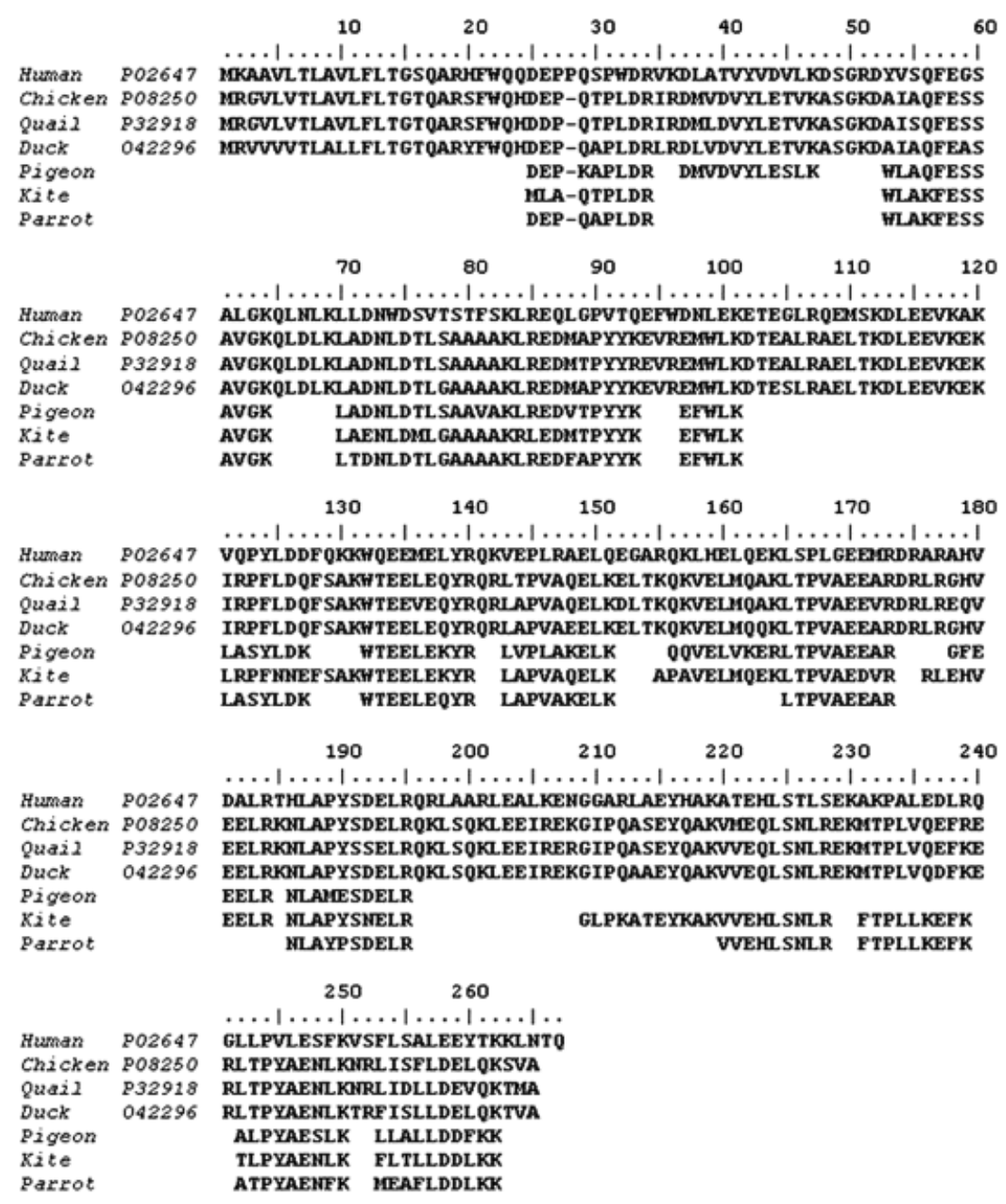

Figure 2. Sequence alignment of proapoliprotein A-I from human (Homo sapiens, UniProt P02647), chicken (Gallus gallus, UniProt P08250), quail (Coturnix japonica, UniProt P32918), duck (Anas platyrhynchos, UniProt 042296), and turkey (Meleagris gallopavo, UniProt A4GUJ5) with peptides resulting from trypsin digestion of the protein contained in the $\alpha$-globulin band in plasma from a black kite (Milvus migrans), a rock pigeon (Columba livia), and an orange-winged parrot (Amazona amazonica). The peptide sequences correspond to those determined by liquid chromatography coupled to tandem mass spectrometry (LC-MS/MS) and de novo sequencing.

the Uniprot database allowed us to unequivocally identify apo A-I as the main or only protein in the peak. The absence of the expected $24 \mathrm{~N}$-terminal amino acids, based on alignment with the chicken sequence, could mean that the apolipoprotein in the 3 species we studied was a mature circulating form. The missing sequence corresponds to an 18-amino-acid prepeptide, which may act as a signal peptide, and to a 6-amino-acid propeptide. 7,19,20 Indeed, the conversion of proapo A-I to mature apo A-I requires the proteolytic cleavage of these 24 amino acids. ${ }^{7}$ Some small sequences were not identified in this study. This is likely because trypsin systematically cuts peptides at the C-terminal of lysine or arginine. If they are too small, such peptides cannot be identified by mass spectrometry.

Apo A-I is the most abundant apolipoprotein in the high-density lipoprotein (HDL) fraction in both birds and mammals. ${ }^{7,21,22}$ Apo A-I is an amphipathic protein, in which hydrophilic regions interact with polar surface lipids and hydrophobic regions interact with core lipids. These interactions contribute to the stability of apo A-I and allow the solubilization of hydrophobic lipids in an aqueous environment such as blood..$^{23}$ In birds, HDLs are responsible for the redistribution of cholesterol, cholesterol esters, and other nonpolar lipids from peripheral tissues to the liver for reuse or excretion in the bile. ${ }^{23,24}$ Apo A-I therefore 
plays a pivotal role in cholesterol homeostasis, through reverse cholesterol transport. ${ }^{23,25}$

In the present study, apo A-I appeared to be very abundant in pigeons and black kites, where the $\alpha$-globulin peaks comprised up to one-third of the total protein content. This was consistent with findings in other studies indicating that HDL and cholesterol concentrations in pigeons are higher than those in most other avian species, with total plasma cholesterol concentration averaging $7.7 \mathrm{mmol} / \mathrm{L}$, and $75-80 \%$ of cholesterol present in the form of HDL. ${ }^{26,27}$

High concentrations of apo A-I could be the result of an adaptation to the peculiar lipid metabolism of certain types of birds in which fatty acids are the primary source of fuel during long-distance flights. ${ }^{28,29}$ This could explain the lower concentration of apo A-I in orange-winged parrots (a sedentary species) compared with black kites and pigeons, which are migrant birds. High apo A-I concentration could also be the result of adaptation to potentially high cell membrane turnover associated with the higher metabolic rate of birds compared with mammals of the same weight. ${ }^{30-32}$ Further studies are needed to investigate apo A-I peaks in other avian species over a range of physiologic conditions such as egg laying, molting, premigratory hyperphagia, and migration. Such investigations may lead to a more thorough understanding of the role of apo A-I in birds.

The high concentration of apo A-I and its presence in the $\alpha$-globulin region of the 3 species studied must be taken into account when interpreting electrophoretograms. Such a peak could be incorrectly interpreted as resulting from inflammation, because numerous positive acute phase proteins such as $\alpha$-1 antitrypsin and $\alpha-2$ macroglobulin have been reported to migrate into the $\alpha$-region in birds. ${ }^{2}$ Apo A-I, like albumin, is a negative acute phase protein in chickens ${ }^{33}$ (as well as in humans ${ }^{34,35}$ ) such that its plasma concentration decreases in inflammation and may affect the albumin:globulin ratio.

\section{Acknowledgments}

We wish to thank the Plateau d'Analyse Protéomique par Séquençage et Spectrométrie de masse (PAPSS, INRA, Jouy-en-Josas) which performed the mass spectrometry experiments, J.L. Liégeois from the Académie de fauconnerie du Puy du fou (France) for the black kite blood samples, D. Ordonneau from the Zoo de Lille for the orange winged parrots samples, P. Trolliet from Sebia for his invaluable technical support, the Muséum national d'Histoire naturelle and the Conseil Général de Seine Maritime (France) for their financial support, and Glenn Lund from Techtrans Consulting for the English proofreading.

\section{References}

1. Lumeij JT. The diagnostic value of plasma proteins and non-protein nitrogen substances in birds. Vet Quart. 1987;9:262-268.

2. Cray C, Tatum L. Application of protein electrophoresis in avian diagnostic testing. $J$ Av Med Surg. 1998;12: 4-10.

3. Werner LL, Reavill DR. The diagnostic utility of serum protein electrophoresis. Vet Clin North Am Exot Anim Pract. 1999;2:651-662.

4. Sibley CG, Hendrickson HT. A comparative electrophoretic study of avian plasma proteins. The Condor. 1970;72:43-49.

5. Zaias J, Fox WP, Cray C, Altman NH. Hematologic, plasma protein, and biochemical profiles of brown pelicans (Pelecanus occidentalis). Am J Vet Res. 2000;61:771-774.

6. Cray C, Rodriguez M, Zaias J. Protein electrophoresis of psittacine plasma. Vet Clin Pathol. 2007;36:64-72.

7. Karathanasis SK, Zannis VI, Breslow JL. Isolation and characterization of the human apolipoprotein A-I gene. Proc Natl Acad Sci USA. 1983;80:6147-6151.

8. Tatum LM, Zaias J, Mealey BK, Cray C, Bossard GD. Protein electrophoresis as a diagnostic and prognostic tool in raptor medicine. $J$ Zoo Wildl Med. 2000;31:497-502.

9. Gayathri KL, Hegde SN. Alteration in haematocrit values and plasma protein fractions during the breeding cycle of female pigeons, Columba livia. Anim Reprod Sci. 2006;91:133-141.

10. Ferrer M, Garcia-Rodríguez T, Carrillo JC, Castroviejo J. Hematocrit and blood chemistry values in captive raptors (Gyps fulvus, Buteo buteo, Milvus migrans, Aquila heliaca). Comp Biochem Physiol A. 1987;87:1123-1127.

11. Lumeij JT, Remple JD, Remple CJ, Riddle KE. Plasma chemistry in peregrine falcons (Falco peregrinus): reference values and physiological variations of importance for interpretation. Avian Pathol. 1998;27:129-132.

12. Lanzarot MP, Montesinos A, San Andrés MI, Rodrígues C, Barahona MV. Hematological, protein electrophoresis and cholinesterase values of free-living nestling peregrine falcons in Spain. $J$ Wildl Dis. 2001;37:172-177.

13. Spagnolo V, Crippa V, Marzia A, Sartorelli P. Reference intervals for hematologic and biochemical constituents and protein electrophoretic fractions in captive common buzzards (Buteo Buteo). Vet Clin Pathol. 2006;35:82-87.

14. Balasch J, Palomeque J, Palacios L, Musquera S, Jimenez M. Hematological values of some great flying 
and aquatic-diving birds. Comp Biochem Physiol A. 1974;49:137-145.

15. Lumeij JT, De Bruijne JJ. Blood chemistry reference values in racing pigeons (Columba livia domestica). Avian Pathol. 1985; 14:401-408.

16. Clubb SL, Schubot RM, Joyner K, et al. Hematological and serum biochemical reference intervals in juvenile eclectus parrots (Eclectus roratus). J Assoc Avian Vet. 1990;4:218-225.

17. Clubb SL, Schubot RM, Joyner K, et al. Hematologic and serum biochemical reference intervals in juvenile cockatoos. J Assoc Avian Vet. 1991;5:16-26.

18. Clubb SL, Schubot RM, Joyner K, et al. Hematologic and serum biochemical reference intervals in juvenile macaws (Ara sp.). J Assoc Avian Vet. 1991;5:154-162.

19. Cheung P, Chan L. Nucleotide sequence of cloned cDNA of human apolipoprotein A-I. Nucleic Acids Res. 1983;11:3703-3715.

20. Byrnes L, Luo CC, Li WH, Yang CY, Chan L. Chicken apolipoprotein A-I: cDNA sequence, tissue expression and evolution. Biochem Biophys Res Commun. 1987;148:485-492.

21. Banerjee D, Redman C. Biosynthesis of high density lipoprotein by chicken liver: conjugation of nascent lipids with apoprotein A1. J Cell Biol. 1984;99: 1917-1926.

22. Douaire M, Le Fur N, el Khadir-Mounier C, Langlois P, Flamant F, Mallard J. Identifying genes involved in the variability of genetic fatness in the growing chicken. Poult Sci. 1992;71:1911-1920.

23. Kiss RS, Ryan RO, Francis GA. Functional similarities of human and chicken apolipoprotein A-I: dependence on secondary and tertiary rather than primary structure. Biochim Biophys Acta. 2001;1531:251-259.

24. Klasing KC. Lipids. In: Klasing KC, ed. Comparative Avian Nutrition. New York, NY: CAB International; 2000:171-200.

25. Blue ML, Ostapchuk P, Gordon JS, Williams DL. Synthesis of apolipoprotein A-I by peripheral tissues of the rooster. A possible mechanism of cellular cholesterol efflux. J Biol Chem. 1982;257:11151-11159.

26. Chapman MJ. Animal lipoproteins: chemistry, structure, and comparative aspects. J Lipid Res. 1980;21:789-853.

27. Barakat HA, St.Clair RW. Characterization of plasma lipoproteins of grain- and cholesterol-fed White Carneau and Show Racer pigeons. J Lipid Res. 1985;26:1252-1268.

28. Butler PJ. Exercise in birds. J Exp Biol. 1991;160:233-262.

29. Butler PJ, Bishop CM. Flight. In: Whittow GC, ed. Sturkie's Avian Physiology. San Diego, CA: Academic Press; 2000:391-435.

30. Rodnan GP, Ebaugh FG, Spivey Fox MR. The life span of the red blood cell and the red blood cell volume in the chicken, pigeon and duck as estimated by the use of $\mathrm{Na}_{2} \mathrm{Cr}_{51} \mathrm{O}_{4}$, with observations on red cell turnover rate in the mammal, bird and reptile. Blood. 1957;12: 355-366.

31. Walsberg GE. Avian ecological energetics. In: Farner DS, King JR, Parkes KC, eds. Avian Biology. Vol. 7. New York, NY: Academic Press; 1983: 161-220.

32. Hulbert AJ. Membrane fatty acids as pacemakers of animal metabolism. Lipids. 2007;42:811-819.

33. Upragarin N, Toussaint MJM, Tooten PCJ, Ajan V, Wajjwalku W, Gruys E. Acute phase protein reaction in layer chickens. A calculated acute phase protein index as measure to assess health during the rearing period. Proceedings of the 5th Colloquium on Animal Acute Phase Proteins, Dublin, Ireland, 2005, 40.

34. Whicher JT, Bienvenu J, Price CP. Molecular biology, measurement and clinical utility of the acute phase proteins. Pure Appl Chem. 1991;63:1111-1116.

35. Monnet D, Edjeme NE, Ndri K, et al. La lipoprotéine (a) et les protéines de la phase aiguë de l'inflammation au cours de la crise drépanocytaire homozygote. Ann Biol Clin. 2002;60:101-103. 